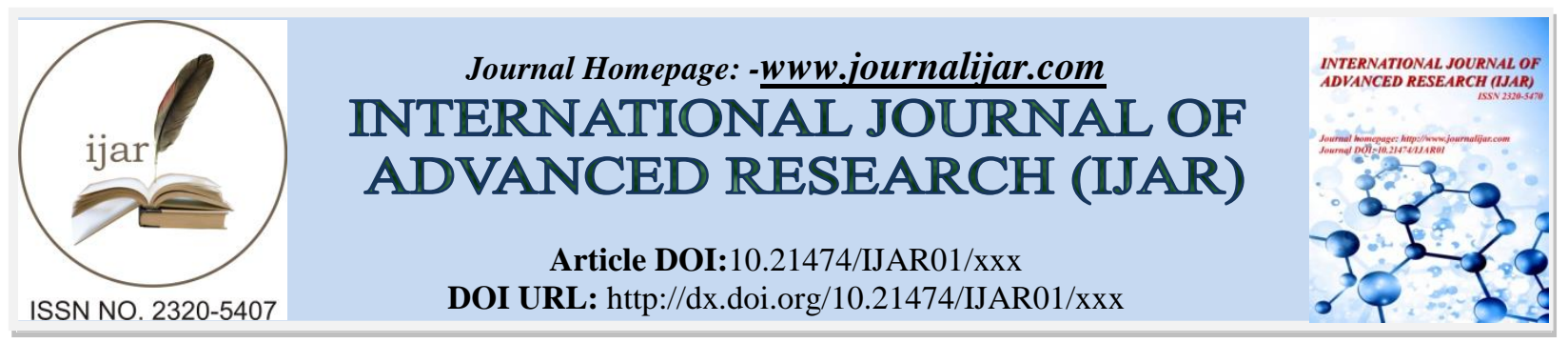

RESEARCH ARTICLE

\title{
EFFECT OF MIXED SOLVENT SYSTEM ON INTRAMOLECULAR INTERACTIONS OF METAL MEDIATED TERNARY COMPLEXES OF BETA-HYDROXY KETONE DERIVATIVES AND BENZOTRIAZOLE DERIVATIVES IN SOLUTION.
}

\section{"Dr. Sridarala Ramu ${ }^{1}$ and Siddhartha Marupati ${ }^{2}$}

1. Professor, Department of Humanities and Sciences, Vardhaman College of Engineering, Shamshabad, Hyderabad-501218, Telangana State, India.

2. Assistant Professor, Department of Humanities and Sciences, Vardhaman College of Engineering, Shamshabad, Hyderabad-501218, Telangana State, India.

\section{Manuscript Info}

Manuscript History

Received: 27 March 2017

Final Accepted: 30 April 2017

Published: May 2017

Key words:-

Ternary complexes, Ionization constants, stability constants, intramolecular interactions, stacking interactions.

\section{Abstract}

The stabilities of ternary complexes of metal ions (copper, nickel, zinc and cobalt) with beta-hydroxy ketone(BHK) derivatives and benzotriazole(BTAZ) derivatives in various mixed solvent systems (Water+Dioxane) medium in $0.1 \mathrm{M} \mathrm{KNO3}$ ionic strength at $25^{\circ} \mathrm{C}$ using $\mathrm{pH}$ metric titration method have been established. The data reveal that the copper forms more stable complexes, which is followed by zinc and $\mathrm{Ni}$ complexes with these ligands. Cobalt form less stable complexes with these ligands. The stabilities of these complexes are further quantified with $\Delta \log \mathrm{K}$ values, intra-molecular equilibrium constants and percentage of stacking interaction in the ternary systems. The observed positive $\Delta \log \mathrm{K}$ values suggest that the flexible side chain alkyl moiety (ethyl group, butyl group) or aromatic moiety (phenyl group) in BHK ligand overlaps with the fixed aromatic moiety of BTAZ ligand in the ternary complex, which results in the enhanced stabilities for the (BHK-Alk)-Metal(II)-BTAZ and (BHK$\mathrm{Ph}$ )-Metal(II)-BTAZ systems. Interestingly, the positive $\Delta \log \mathrm{K}$ values for both BHK-Alk and BHK-Ph ligands in their corresponding ternary complexes are about the same. This suggests the flexible Alkyl or phenyl side chain of BHK is overlapping with the triazole ring, but not the phenoxy ring of the BTAZ ligand.

Copy Right, IJAR, 2017,. All rights reserved.

\section{Introduction:-}

A metal ion interactions with various ligands is an extremely diversified field [1-11], because the interaction as well as the resulting complex can have different applications in the biological field [12-21], development of luminescent materials, color stabilizing agents for toners in color photography, catalysts, therapeutic advantage [22-34], in the electronic display devices [35-47] or fluorescent probes [48-58] and can also be used in the resin technology [5965]. In all these cases, the utility of metal-ligand complex is directly related to the stability of the complex which is a tunable parameter.

The ligand can be a biomolecule [66-70] or a complexing agent [71-75] or simply scientifically a designed compound [76-80]. Both the metal ion interactions with the ligands and the metal-ligand complexes have been 
constantly growing because of their demand or applications in various fields and therefore they are getting the attention of scientists from the divergent areas. Both metal ion and ligand contribute towards the overall stability of metal-ligand complex [81].

These stabilities are directly depend on (i) the structure of the ligand, (ii) nature of the metal ion, (iii) intramolecular interactions between the bound ligands in the metal mediated complex, and (iv) the medium for the complex formation, such as temperature, solvent or ionic strength etc [82]. The study of such large area, with respect to metal ion binding, is very complex, because there are several metal ions or millions of compounds and their combination provides exponential number of metal-ligand complexes [83-84]. Moreover, the properties of these interactions or complexes are highly sensitive to the reaction conditions in addition to nature of metal ion and donor atoms of the ligands. Therefore, it has been a big challenge for the scientific community to understand the metalligand interactions.

In a simple model, a single metal ion binds to a single ligand in a 1:1 ratio, it is called a binary complex. If a single metal ion binds to a two different ligands then the complex is called mixed ligand complex or ternary complex. The complexity of analysis increases in multi-ligand and multi-metal complexes. The stabilities of the multi-ligand complexes are very unpredictable, because the flexible side chains of bound ligands participate in the ligand-ligand interactions, which play a major role in the overall stability of the complexes. The interactions of metal ions with the ligands are measured in terms of formation constant or stability constants $(\log \mathrm{K})$ and it can be estimated or predicted based on the ligand coordination atoms, the charges of coordinated atoms and metal ions, and the chelate ring size in the complex [85].

However, in some cases, the intramolecular non-covalent interactions between ligands can contribute a significant role in the overall binding energy of the complex. These interactions include hydrogen bonding, Ionic or electrostatic interactions, hydrophobic interactions [86-87], and stacking interactions between the ligands of the complex. Most of the time the predicted stabilities of the metal ligand complexes, based on the $\mathrm{pK}_{\mathrm{a}}$ values of the ligands, differ from the experimental values. This is because of the fact that the intramolecular interactions exist between the coordinated ligands in the metal complex and also these interactions are depend on the orientation of the side chains of the ligands. The easy and quick technique to find out the properties of metal ligand complexes is $\mathrm{pH}$ metric method and is being used in exploring the interactions of metal ligand(s) complexes in solution [88-90].

In order to get more information on the intramolecular interactions and their contribution towards the overall stability of metal ligand complexes, in this investigation, we selected beta-hydroxy ketone (BHK) derivatives and benzotriazole (BTAZ) derivatives as ligands, and $\mathrm{Cu}(\mathrm{II}), \mathrm{Ni}(\mathrm{II}), \mathrm{Zn}(\mathrm{II})$ and $\mathrm{Co}(\mathrm{II})$ as metal ions in the formation of metal ligand complexes. The metal complexes of beta-hydroxy ketone (BHK) and benzotriazole (BTAZ) derivatives have several industrial applications. For example, metal complexes of BHK are known to use as a fluorescent probes or insecticides [91] whereas metal complexes of BTAZ used as catalysts in organic synthesis [92]. The selected betahydroxy ketone derivative has a methyl or ethyl or butyl or aromatic substitution in a flexible side chain and this side chain is not involved in the metal coordination. The selected second ligand, benzotriazole derivative, which has benzotriazole ring connected to ethanol or phenol side chain, and this side chain involved in the coordination with the metal ion.

The objective of this investigation is to identify the Effect of solvent on the stabilities of metal ligand complexes and intramolecular interactions and their contributions towards the overall stabilities of metal-ligand complexes. In this investigation we explore, how the side chain groups from BHK interact with fixed aromatic moieties of bound BTAZ ligand to the metal ion and its effect on the overall stability of the ternary metal-ligand complexes in solution. In this report we show that the flexible ethyl, butyl and phenyl side chain of beta-hydroxy ketone involves in the intramolecular interaction with the benzotriazole ring, but not phenoxy ring of benzotriazole derivative.

\section{Experimental:-}

The ligands from beta-hydroxy ketone (BHK) derivatives are shown in Figure 1 (a)-(d). The BHK ligands consisting of trifluoromethyl group in the compound. The listed ligands differ from each other at their terminal positions. The formula (a) is abbreviated as BHK-Me, the formula (b) is abbreviated as BHK-Et, the formula (c) is abbreviated as BHK-Bu, and the formula (d) is abbreviated as BHK-Ph, where BHK is $\mathrm{CF} 3-\mathrm{C}(\mathrm{OH})=\mathrm{CH}-\mathrm{C}(=\mathrm{O})-\mathrm{CH} 2-, \mathrm{Me}$ is methyl, Et is ethyl, $\mathrm{Bu}$ is butyl and $\mathrm{Ph}$ is - $\mathrm{CH} 2$-phenyl group. 
The ligands from benzotriazole (BTAZ) derivatives are shown in Figure 1(e)-(h). The listed ligands differed by substituted alcohol and amino group. The formula (e) is abbreviated as BTAZ-Alk-OH, the formula (f) is abbreviated as BTAZ-Ph-OH, the formula $(\mathrm{g})$ is abbreviated as BTAZ-Alk- $\mathrm{NH}_{2}$, the formula $(\mathrm{h})$ is abbreviated as BTAZ-Ph- $\mathrm{NH}_{2}$ where Alk is - $\mathrm{CH} 2-\mathrm{CH} 2-$ and $\mathrm{Ph}$ is -phenyl group.<smiles>CCC(=O)C=C(O)C(F)(F)F</smiles>

(a) BHK-Me<smiles>CCCC(=O)C=C(C)O</smiles>

(b) BHK-Et<smiles>CC(C)CCC(=O)C=C(O)C(F)(F)F</smiles>

(c) BHK-Bu<smiles>N#CC(O)=CC(=O)O</smiles>

(d) BHK-Ph

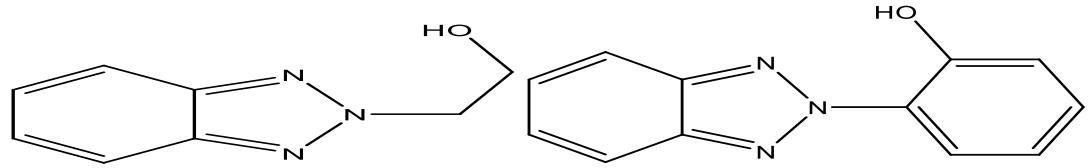

(e) BTAZ-Alk-OH

(f) BTAZ-Ph-OH

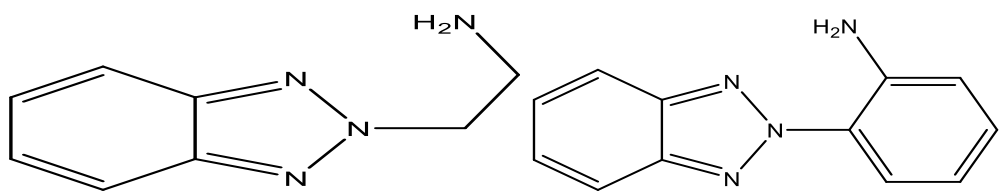

(g) BTAZ-Alk-NH

(h) BTAZ-Ph-NH

Figure 1:- Beta-hydroxy ketone (BHK) derivatives (a)-(d) and Benzotriazole (BTAZ) derivatives (e)-(h)

The above ligands are synthesized and purified in our laboratory (unpublished data).

Metal salts of $\mathrm{Cu}(\mathrm{II}), \mathrm{Ni}(\mathrm{II}), \mathrm{Co}(\mathrm{II})$ and $\mathrm{Zn}(\mathrm{II})$ were AR grade chemicals. All the metal ions were standardized with disodium salt of EDTA [93]. Carbonate free sodium hydroxide was prepared and standardized by titration with potassium acid phthalate [94]. Stock solutions of metal ion were prepared from double distilled water. For every titration, fresh solid ligand was weighed out into the reaction cell to avoid possible hydrolysis.

The experimental method consisted of $\mathrm{pH}$ metric titration. A digital $\mathrm{pH}$ meter with a combination electrode was used to determine the hydrogen ion concentration.

\section{Calibration of $\mathrm{pH}$ meter:-}

A digital $\mathrm{pH}$ meter fitted with a combination electrode was used in the determination of the hydrogen ion concentration. Two buffer solutions of different $\mathrm{pH}$ values have to be selected. The first buffer solution should have a $\mathrm{pH}$ value 4.The second buffer solution should have a $\mathrm{pH}$ value 7 . The combination electrode system has to be rinsed with deionised water and dried with tissue paper. Place the electrode system in to the $\mathrm{pH} 4$ buffer solution. The electrode system has to stay in the buffer solution for a short time, at least for one minute, and adjust calibration button till the indication of the $\mathrm{pH}$ meter settles near the $\mathrm{pH}$ value of the buffer solution $(\mathrm{pH} 4)$ and becomes stable. Remove out electrodes from buffer solution and rinse with deionised water and dried with tissue paper. Place electrode system in to the $\mathrm{pH} 7$ buffer solution. The electrode system has to stay in the buffer solution for a short time, at least for one minute, and adjust calibration button till the indication of the $\mathrm{pH}$ meter settles near the $\mathrm{pH}$ value of the buffer solution ( $\mathrm{pH} 7)$ and becomes stable. Remove out electrodes from buffer solution and rinse with deionised water and dried with tissue paper. Place the electrode system back in to the $\mathrm{pH} 4$ buffer solution to make sure it is stable.

\section{Free ligand systems:-}

The free ligands with standard sodium hydroxide in the absence and in the presence of above mentioned metal ions being investigated. The titrations were carried out in a magnetically stirred double-walled reaction cell maintained constant $25^{\circ} \mathrm{C}$ temperature, in various mixed solvent systems (Water+Dioxane). The amount of Water: Dioxane 
various from $25: 75 ; 50: 50 ; 75: 25$. The ionic strength was maintained constant by using $0.10 \mathrm{M}$ KNO3 as a supporting electrolyte and relatively low concentration of the ligand and metal ion $\left(1 \times 10^{-3} \mathrm{M}\right)$. During the course of titration a stream of nitrogen was passed over the solution to eliminate the adverse effect of atmospheric carbon dioxide. For every titration, fresh solid ligand was weighed out into the reaction cell to avoid possible concentration effects. The efficiency of the thermostat was accurate to $\pm 0.1{ }^{\circ} \mathrm{C}$. The calibration was done before and after each experiment to avoid any errors that may arise from the faulty electrode system.

\section{Binary systems:-}

The experimental method consisted of $\mathrm{pH}$ metric titration of ligands with standard $\mathrm{NaOH}$ solution in the presence of various metal ions, viz., $\mathrm{Cu}(\mathrm{II}), \mathrm{Ni}(\mathrm{II}), \mathrm{Zn}(\mathrm{II})$ and $\mathrm{Co}(\mathrm{II})$, in an equimolar stoichiometric ratios.

\section{Ternary systems:-}

In ternary systems the experiments were done in a 1:1:1 ratio of the individual beta-hydroxy ketone (BHK) derivative ligands, benzotriozole derivatives (BTAZ) derivative ligands and metal ions. The other experimental conditions maintained for binary and ternary systems were similar to those described for free ligand systems.

\section{Calculations:-}

The ionization constants of various ligands were calculated using the computer program PKAS [95]. Entire pH range from the titration data has been given for the calculation of $\mathrm{pKa}$ values using the computer program. All the formation or stability constants were subjected to refinement using the computer program BEST [95]. The refinement of the stability constants of binary and ternary systems were done by considering all possible species present in the solution, i.e., $\mathrm{HL}^{+}$, HA, L-, A-, ML, ML2, MA, MA2 and MAL etc, where L and A are different ligands in the complex. The refined values for these complexes thus obtained are provided in the Tables. The error limits in these constants were minimized (sigma fit is 0.001).

\section{Results and Discussion:-}

Dissociation constants of ligands:-

The $\mathrm{pH}$ metric titration of BHK ligands took one mole of base per mole of ligand to complete deprotonate the ligand. The dissociation constant $(\mathrm{pKa})$ for these ligands were calculated from the experimental points taken between $\mathrm{a}=0$ and $\mathrm{a}=1$ ( $\mathrm{a}$ is moles of bases added per mole of ligand).

(i) Beta-hydroxy ketone (BHK) derivatives: The ionization constant of BHK derivative ligand is related to the usual equilibrium dissociation

$$
\mathrm{HA} \rightleftharpoons \mathrm{A}^{-}+\mathrm{H}^{+}
$$

where $\mathrm{HA}$ is $\mathrm{BHK}$ ligand, $\mathrm{A}^{-}$is dissociated $\mathrm{BHK}$ ligand and $\mathrm{H}^{+}$is proton

The pKa values for these ligands are listed in Table 1 . The single $\mathrm{pKa}$ value from the dissociation of $\mathrm{H}^{+}$is from the $-\mathrm{OH}$ group on the ligand.

The $\mathrm{pH}$ metric titration curve of BTAZ ligands show an inflection at $\mathrm{a}=1$ followed by buffer region at high $\mathrm{pH}$. The $\mathrm{pKa}$ and $\mathrm{pK} 2 \mathrm{a}$ for these ligands were calculated between $\mathrm{a}=0$ and $\mathrm{a}=1$, and $\mathrm{a}=1$ and $\mathrm{a}=2$ respectively and the constants are listed in Table 2.

(ii) Benzotriazole (BTAZ) derivatives having amino group on the side chain: The ionization of di-protonated BTAZ derivative ligand can be represented by the following equilibrium:

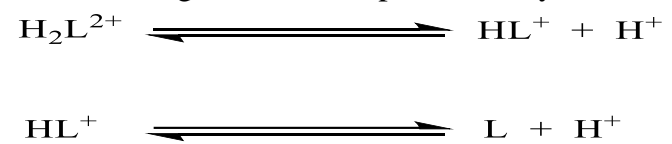

where $\mathrm{H}_{2} \mathrm{~L}^{2+}$ is di-protonated BTAZ ligand, $\mathrm{HL}^{+}$is monoprotonated BTAZ ligand and L is fully deprotonated BTAZ ligand and $\mathrm{H}^{+}$is proton .

(iii) Benzotriazole (BTAZ) derivatives having hydroxyl group on the side chain: The ionization of di-protonated BTAZ derivative ligand can be represented by the following equilibrium: 
$\mathrm{H}_{2} \mathrm{~L}^{+} \rightleftharpoons \mathrm{HL}+\mathrm{H}^{+}$

$\mathrm{HL} \rightleftharpoons \mathrm{L}^{-}+\mathrm{H}^{+}$

Where $\mathrm{H}_{2} \mathrm{~L}^{+}$is mono-protonated BTAZ ligand, HL is BTAZ ligand and $\mathrm{L}^{-}$is dissociated BTAZ ligand and $\mathrm{H}^{+}$is proton.

\section{Effect Of Solvent On The Stabilities Of Metal Ligand Complexes:-}

The properties of metal ion interactions with ligand can be tunable and the effect of solvent is one of the way to control such properties. So, the solvent system or medium for the metal ion interaction is critical for optimizing the stabilities of metal ligand complexes. The role of solvent on metal-ligand interactions will provide a more comprehensive understanding of solvent dependent nature of metal-ligand interactions and ligand-ligand interactions in binary and ternary systems in solution [96-97]. Specifically, solvent plays an important role in ligand-ligand interactions in ternary complexes and therefore, it is useful in the identification of intramolecular interactions in ternary complexes [98-101].

The dissociation constants for the ligands at various solvent ratios are listed in Tables 1 and 2 . The pK $\mathrm{a}_{\mathrm{a}}$ values decrease with increase with amount of the water in the solvent system. In other words increase in the amount of water decrease the $\mathrm{pKa}$ value, because water increases the polarity of the reaction medium, which increases the dissociation of proton from the ligand and therefore, lower $\mathrm{pKa}$ values are expected.

Table 1:- Ionization constants $\left(\mathrm{pK}_{\mathrm{a}}\right)$ of Beta-hydroxy ketone $(\mathrm{BHK})$ derivatives in various mixed Solvent Systems (Water + Dioxane) and in $0.10 \mathrm{~mol} \mathrm{dm}{ }^{-3}\left(\mathrm{KNO}_{3}\right)$ at $25^{\circ} \mathrm{C}$

\begin{tabular}{|c|c|c|c|}
\hline Ligand & $\begin{array}{c}\text { Solvent ratio } \\
\text { (Water: Dioxane) }\end{array}$ & $\mathrm{pK}_{\mathrm{a}}$ & $\mathrm{pK}_{2 \mathrm{a}}$ \\
\hline \multirow[t]{3}{*}{ BHK-Me } & $25: 75$ & 10.39 & ---- \\
\hline & $50: 50$ & 9.88 & ---- \\
\hline & $75: 25$ & 9.37 & ---- \\
\hline \multirow[t]{3}{*}{ BHK-Et } & $25: 75$ & 10.51 & ---- \\
\hline & $50: 50$ & 9.99 & ---- \\
\hline & $75: 25$ & 9.48 & ---- \\
\hline \multirow[t]{3}{*}{$\mathrm{BHK}-\mathrm{Bu}$} & $25: 75$ & 10.67 & ---- \\
\hline & $50: 50$ & 10.16 & ---- \\
\hline & $75: 25$ & 9.67 & ---- \\
\hline \multirow[t]{3}{*}{ BHK-Ph } & $25: 75$ & 10.88 & ---- \\
\hline & $50: 50$ & 10.36 & ---- \\
\hline & $75: 25$ & 9.82 & ---- \\
\hline
\end{tabular}

Table 2:- Ionization constants $\left(\mathrm{pK}_{\mathrm{a}}\right)$ of Benzotriazole (BTAZ) derivatives in various mixed Solvent Systems (Water + Dioxane) in $0.10 \mathrm{~mol} \mathrm{dm}^{-3}\left(\mathrm{KNO}_{3}\right)$ at $25^{\circ} \mathrm{C}$

\begin{tabular}{|c|c|c|c|}
\hline Ligand & $\begin{array}{c}\text { Solvent ratio } \\
\text { (Water: Dioxane) }\end{array}$ & $\mathrm{pK}_{\mathrm{a}}$ & $\mathrm{pK}_{2 \mathrm{a}}$ \\
\hline \multirow[t]{3}{*}{ BTAZ-Alk-OH } & $25: 75$ & 6.66 & 10.28 \\
\hline & $50: 50$ & 6.55 & 9.82 \\
\hline & $75: 25$ & 6.44 & 9.37 \\
\hline \multirow[t]{3}{*}{ BTAZ-Ph-OH } & $25: 75$ & 6.85 & 10.67 \\
\hline & $50: 50$ & 6.74 & 10.22 \\
\hline & $75: 25$ & 6.63 & 9.77 \\
\hline \multirow[t]{3}{*}{ BTAZ-Alk-NH ${ }_{2}$} & $25: 75$ & 6.61 & 9.33 \\
\hline & $50: 50$ & 6.51 & 9.22 \\
\hline & $75: 25$ & 6.42 & 9.12 \\
\hline \multirow[t]{3}{*}{ BTAZ-Ph-NH} & $25: 75$ & 7.82 & 9.44 \\
\hline & $50: 50$ & 6.72 & 9.33 \\
\hline & $75: 25$ & 6.61 & 9.23 \\
\hline
\end{tabular}




\section{Stabilities of binary Complexes:-}

The stability constants for the binary systems (1:1) in various amounts of water and dioxane are listed in Tables 3 and 4. It appears that the stability constants decrease with increase in the water amount in the solvent system.

Table 3:- Stability constants $(\log \mathrm{K})$ for the interaction of metal ions with Beta-hydroxy ketone (BHK) derivatives in 1:1 ratio in various mixed Solvent Systems (Water + Dioxane) and in $0.10 \mathrm{~mol} \mathrm{dm}^{-3}\left(\mathrm{KNO}_{3}\right)$ at $25^{\circ} \mathrm{C}$

\begin{tabular}{|c|c|c|c|c|c|}
\hline Ligand & $\begin{array}{c}\text { Solvent ratio } \\
\text { (Water: Dioxane) }\end{array}$ & $\mathrm{Cu}(\mathrm{II})$ & $\mathrm{Ni}(\mathrm{II})$ & $\mathrm{Zn}$ (II) & $\mathrm{Co}$ (II) \\
\hline \multirow{3}{*}{ BHK-Me } & $25: 75$ & 7.22 & 5.05 & 4.22 & 4.16 \\
\cline { 2 - 5 } & $50: 50$ & 6.62 & 4.45 & 3.62 & 3.56 \\
\cline { 2 - 5 } & $75: 25$ & 6.01 & 3.85 & 3.01 & 2.96 \\
\hline \multirow{3}{*}{ BHK-Et } & $25: 75$ & 6.91 & 4.64 & 3.74 & 3.83 \\
\cline { 2 - 5 } & $50: 50$ & 6.33 & 4.24 & 3.33 & 3.25 \\
\cline { 2 - 5 } & $75: 25$ & 6.73 & 3.64 & 2.73 & 2.69 \\
\hline \multirow{2}{*}{ BHK-Bu } & $25: 75$ & 6.03 & 3.52 & 3.73 & 3.51 \\
\cline { 2 - 5 } & $50: 50$ & 5.53 & 3.32 & 2.53 & 2.29 \\
\hline \multirow{2}{*}{ BHK-Ph } & $75: 25$ & 6.61 & 4.42 & 3.73 & 3.51 \\
\cline { 2 - 5 } & $25: 75$ & 5.42 & 3.81 & 3.12 & 2.92 \\
\cline { 2 - 5 } & $50: 50$ & & 2.53 & 2.33 \\
\hline
\end{tabular}

Table 4:- Stability constants $(\log \mathrm{K})$ for the interaction of metal ions with Benzotriazole (BTAZ) derivatives in 1:1 ratio in various mixed Solvent Systems (Water + Dioxane) and in $0.10 \mathrm{~mol} \mathrm{dm}^{-3}\left(\mathrm{KNO}_{3}\right)$ at $25^{\circ} \mathrm{C}$

\begin{tabular}{|c|c|c|c|c|c|}
\hline \multirow{2}{*}{ Ligand } & $\begin{array}{c}\text { Solvent ratio } \\
\text { (Water: Dioxane) }\end{array}$ & $\mathrm{Cu}(\mathrm{II})$ & $\mathrm{Ni}(\mathrm{II})$ & $\mathrm{Zn}$ (II) & $\mathrm{Co}$ (II) \\
\hline \multirow{3}{*}{ BTAZ-Alk-OH } & $25: 75$ & 8.91 & 6.19 & 6.47 & 6.03 \\
\cline { 2 - 5 } & $50: 50$ & 8.71 & 5.98 & 6.28 & 5.83 \\
\cline { 2 - 5 } & $75: 25$ & 8.51 & 5.78 & 6.08 & 5.63 \\
\hline \multirow{3}{*}{ BTAZ-Ph-OH } & $25: 75$ & 8.83 & 5.91 & 6.20 & 5.82 \\
\cline { 2 - 6 } & $50: 50$ & 8.65 & 5.78 & 6.01 & 5.63 \\
\cline { 2 - 6 } & $75: 25$ & 8.45 & 5.58 & 5.81 & 5.43 \\
\hline \multirow{2}{*}{ BTAZ-Alk-NH ${ }_{2}$} & $25: 75$ & 9.11 & 6.38 & 6.65 & 6.15 \\
\cline { 2 - 6 } & $50: 50$ & 8.92 & 6.19 & 6.47 & 6.03 \\
\cline { 2 - 6 } & $75: 25$ & 8.72 & 5.99 & 6.27 & 5.83 \\
\hline \multirow{2}{*}{ BTAZ-Ph-NH } & $25: 75$ & 8.68 & 5.98 & 6.47 & 6.12 \\
\cline { 2 - 6 } & $50: 50$ & 8.48 & 5.78 & 6.08 & 5.93 \\
\cline { 2 - 6 } & $75: 25$ & & 6.18 & 6.73 \\
\hline
\end{tabular}

Stabilities of Ternary Complexes:-

The stability constants for the ternary systems $(1: 1: 1)$ at various ratios of solvents are listed in Tables 5 to 8 . Similar to binary systems, the stability constants of ternary complexes decrease with increase in the water content in the solvent system indicates that the complex formation is less favorable at higher polar solvent system.

Table 5:- Stability constants $(\log \mathrm{K})$ for the interaction of metal ions with BHK-Me and BTAZ derivatives in (1:1:1) ratio in various mixed Solvent Systems (Water + Dioxane) and in $0.10 \mathrm{~mol} \mathrm{dm}^{-3}\left(\mathrm{KNO}_{3}\right)$ at $25^{\circ} \mathrm{C}$

\begin{tabular}{|c|c|c|c|c|c|}
\hline \multirow{2}{*}{ Ternary Complex } & $\begin{array}{c}\text { Solvent ratio } \\
\text { (Water: Dioxane) }\end{array}$ & \multicolumn{4}{|c|}{ Metal ion } \\
\cline { 2 - 5 } & $25: 75$ & $\mathrm{Cu}(\mathrm{II})$ & $\mathrm{Ni}(\mathrm{II})$ & $\mathrm{Zn}(\mathrm{II})$ & $\mathrm{Co}(\mathrm{II})$ \\
\hline \multirow{2}{*}{$\begin{array}{c}\text { BHK-Me)-(Metal ion)- (BTAZ- } \\
\text { Alk-OH) }\end{array}$} & $50: 50$ & 15.76 & 10.61 & 10.32 & 9.47 \\
\cline { 2 - 5 } & $75: 25$ & 14.98 & 9.82 & 9.52 & 8.68 \\
\cline { 2 - 5 } & $25: 75$ & 15.66 & 9.03 & 8.72 & 7.89 \\
\hline \multirow{2}{*}{$\begin{array}{c}\text { BHK-Me)-(Metal ion)- (BTAZ- } \\
\text { Ph-OH) }\end{array}$} & $50: 50$ & 14.91 & 9.72 & 10.23 & 9.45 \\
\cline { 2 - 6 } & $75: 25$ & 14.07 & 8.82 & 9.42 & 8.67 \\
\cline { 2 - 6 } & $25: 75$ & 15.91 & 10.81 & 10.49 & 9.73 \\
\hline (BHK-Me)-(Metal ion)- (BTAZ- & & &
\end{tabular}




\begin{tabular}{|c|c|c|c|c|c|}
\hline \multirow{2}{*}{ Alk-NH 2$)$} & $50: 50$ & 15.13 & 9.99 & 9.72 & 8.78 \\
\cline { 2 - 6 } & $75: 25$ & 14.37 & 9.22 & 8.93 & 8.07 \\
\hline \multirow{2}{*}{$\begin{array}{c}\text { (BHK-Me)-(Metal ion)- (BTAZ- } \\
\text { Ph-NH }\end{array}$ ) } & $25: 75$ & 15.82 & 10.65 & 10.38 & 9.44 \\
\cline { 2 - 6 } & $50: 50$ & 15.01 & 9.89 & 9.61 & 8.71 \\
\cline { 2 - 6 } & $75: 25$ & 14.14 & 8.99 & 8.75 & 7.99 \\
\hline
\end{tabular}

Table 6:- Stability constants $(\log \mathrm{K})$ for the interaction of metal ions with BHK-Et and BTAZ derivatives in (1:1:1) ratio in various mixed Solvent Systems (Water + Dioxane) and in $0.10 \mathrm{~mol} \mathrm{dm}^{-3}\left(\mathrm{KNO}_{3}\right)$ at $25^{\circ} \mathrm{C}$

\begin{tabular}{|c|c|c|c|c|c|}
\hline \multirow[t]{2}{*}{ Ternary Complex } & \multirow{2}{*}{$\begin{array}{c}\text { Solvent ratio } \\
\text { (Water: Dioxane) }\end{array}$} & \multicolumn{4}{|c|}{ Metal ion } \\
\hline & & $\mathrm{Cu}(\mathrm{II})$ & $\mathrm{Ni}(\mathrm{II})$ & $\mathrm{Zn}(\mathrm{II})$ & $\mathrm{Co}(\mathrm{II})$ \\
\hline \multirow{3}{*}{$\begin{array}{c}\text { (BHK-Et)-(Metal ion)- (BTAZ- } \\
\text { Alk-OH) }\end{array}$} & $25: 75$ & 15.59 & 10.31 & 9.96 & 9.17 \\
\hline & $50: 50$ & 14.82 & 9.71 & 9.38 & 8.38 \\
\hline & $75: 25$ & 14.32 & 9.45 & 8.88 & 8.35 \\
\hline \multirow{3}{*}{$\begin{array}{c}\text { (BHK-Et)-(Metal ion)- (BTAZ-Ph- } \\
\text { OH) }\end{array}$} & $25: 75$ & 15.49 & 10.13 & 9.83 & 9.09 \\
\hline & $50: 50$ & 14.72 & 9.62 & 9.22 & 8.29 \\
\hline & $75: 25$ & 14.25 & 9.26 & 8.60 & 8.15 \\
\hline \multirow{3}{*}{$\begin{array}{c}\text { (BHK-Et)-(Metal ion)- (BTAZ- } \\
\text { Alk-NH2) }\end{array}$} & $25: 75$ & 15.67 & 10.49 & 10.12 & 9.31 \\
\hline & $50: 50$ & 14.92 & 9.93 & 9.52 & 8.62 \\
\hline & $75: 25$ & 14.57 & 9.69 & 9.1 & 8.56 \\
\hline \multirow{3}{*}{$\begin{array}{c}\text { (BHK-Et)-(Metal ion)- (BTAZ-Ph- } \\
\left.\mathrm{NH}_{2}\right)\end{array}$} & $25: 75$ & 15.58 & 10.39 & 10.02 & 9.28 \\
\hline & $50: 50$ & 14.79 & 9.82 & 9.42 & 8.52 \\
\hline & $75: 25$ & 14.34 & 9.48 & 8.92 & 8.48 \\
\hline
\end{tabular}

Table 7:- Stability constants $(\log \mathrm{K})$ for the interaction of metal ions with BHK-Bu and BTAZ derivatives in (1:1:1) ratio in various mixed Solvent Systems (Water + Dioxane) and in $0.10 \mathrm{~mol} \mathrm{dm}^{-3}\left(\mathrm{KNO}_{3}\right)$ at $25^{\circ} \mathrm{C}$

\begin{tabular}{|c|c|c|c|c|c|}
\hline \multirow[t]{2}{*}{ Ternary Complex } & \multirow{2}{*}{$\begin{array}{c}\text { Solvent ratio } \\
\text { (Water: Dioxane) }\end{array}$} & \multicolumn{4}{|c|}{ Metal ion } \\
\hline & & $\mathrm{Cu}(\mathrm{II})$ & $\mathrm{Ni}(\mathrm{II})$ & $\mathrm{Zn}(\mathrm{II})$ & $\mathrm{Co}(\mathrm{II})$ \\
\hline \multirow{3}{*}{$\begin{array}{c}\text { (BHK-Bu)-(Metal ion)- (BTAZ- } \\
\text { Alk-OH) }\end{array}$} & $25: 75$ & 15.57 & 10.72 & 10.25 & 9.55 \\
\hline & $50: 50$ & 14.91 & 9.88 & 9.52 & 8.75 \\
\hline & $75: 25$ & 14.41 & 9.16 & 8.85 & 7.99 \\
\hline \multirow{3}{*}{$\begin{array}{c}\text { (BHK-Bu)-(Metal ion)- (BTAZ- } \\
\text { Ph-OH) }\end{array}$} & $25: 75$ & 15.48 & 10.45 & 9.99 & 9.34 \\
\hline & $50: 50$ & 14.83 & 9.74 & 9.28 & 8.55 \\
\hline & $75: 25$ & 14.32 & 8.95 & 8.55 & 7.79 \\
\hline \multirow{3}{*}{$\begin{array}{c}\text { (BHK-Bu)-(Metal ion)- (BTAZ- } \\
\left.\text { Alk-NH }{ }_{2}\right)\end{array}$} & $25: 75$ & 15.83 & 10.95 & 10.47 & 9.72 \\
\hline & $50: 50$ & 15.29 & 10.22 & 9.82 & 9.04 \\
\hline & $75: 25$ & 14.71 & 9.49 & 9.10 & 8.31 \\
\hline \multirow{3}{*}{$\begin{array}{c}\text { (BHK-Bu)-(Metal ion)- (BTAZ- } \\
\left.\text { Ph-NH } \mathrm{NH}_{2}\right)\end{array}$} & $25: 75$ & 15.59 & 10.76 & 10.29 & 9.68 \\
\hline & $50: 50$ & 15.04 & 10.02 & 9.62 & 8.93 \\
\hline & $75: 25$ & 14.47 & 9.29 & 8.92 & 8.21 \\
\hline
\end{tabular}

Table 8:- Stability constants $(\log \mathrm{K})$ for the interaction of metal ions with BHK-Ph and BTAZ derivatives in (1:1:1) ratio in various mixed Solvent Systems (Water + Dioxane) and in $0.10 \mathrm{~mol} \mathrm{dm}^{-3}\left(\mathrm{KNO}_{3}\right)$ at $25^{\circ} \mathrm{C}$

\begin{tabular}{|c|c|c|c|c|c|}
\hline \multirow[t]{2}{*}{ Ternary Complex } & \multirow{2}{*}{$\begin{array}{c}\text { Solvent ratio } \\
\text { (Water: Dioxane) }\end{array}$} & \multicolumn{4}{|c|}{ Metal ion } \\
\hline & & $\mathrm{Cu}(\mathrm{II})$ & $\mathrm{Ni}(\mathrm{II})$ & $\mathrm{Zn}(\mathrm{II})$ & $\mathrm{Co}(\mathrm{II})$ \\
\hline \multirow{3}{*}{$\begin{array}{l}\text { (BHK-Ph)-(Metal ion)- (BTAZ- } \\
\text { Alk-OH) }\end{array}$} & $25: 75$ & 15.74 & 10.69 & 10.36 & 9.60 \\
\hline & $50: 50$ & 15.39 & 9.92 & 9.79 & 8.88 \\
\hline & $75: 25$ & 14.88 & 9.16 & 9.12 & 8.15 \\
\hline \multirow{3}{*}{$\begin{array}{l}\text { (BHK-Ph)-(Metal ion)- (BTAZ- } \\
\mathrm{Ph}-\mathrm{OH})\end{array}$} & $25: 75$ & 15.65 & 10.47 & 10.08 & 9.41 \\
\hline & $50: 50$ & 15.34 & 9.75 & 9.54 & 8.71 \\
\hline & $75: 25$ & 14.81 & 8.96 & 8.83 & 7.94 \\
\hline \multirow{3}{*}{$\begin{array}{l}\text { (BHK-Ph)-(Metal ion)- (BTAZ- } \\
\left.\text { Alk-NH }{ }_{2}\right)\end{array}$} & $25: 75$ & 15.94 & 10.91 & 10.58 & 9.78 \\
\hline & $50: 50$ & 15.74 & 10.26 & 10.14 & 9.24 \\
\hline & $75: 25$ & 15.28 & 9.54 & 9.39 & 8.39 \\
\hline (BHK-Ph)-(Metal ion)- (BTAZ- & $25: 75$ & 15.74 & 10.72 & 10.43 & 9.75 \\
\hline
\end{tabular}




\begin{tabular}{|l|l|l|l|l|l|}
\hline Ph- $\left.\mathrm{NH}_{2}\right)$ & $50: 50$ & 15.51 & 10.04 & 9.92 & 9.12 \\
\cline { 2 - 5 } & $75: 25$ & 15.05 & 9.32 & 9.18 & 8.29 \\
\hline
\end{tabular}

Quantification of the stabilities of Ternary Complexes:-

The stabilization or destabilization in the formation of ternary complex by solvent system are quantified in terms of $\Delta \log \mathrm{K}$ values at various amounts of solvents are listed in Tables 9 to12.

Table 9:- Quantification of stabilities of (BHK-Me)-metal (II)-BTAZ (1:1:1) ternary complexes in terms of $\Delta \log$ K values at various mixed Solvent Systems

\begin{tabular}{|c|c|c|c|c|}
\hline \multirow[t]{2}{*}{ Ternary Complex } & \multicolumn{4}{|c|}{ Metal ion } \\
\hline & $\mathrm{Cu}(\mathrm{II})$ & $\mathrm{Ni}(\mathrm{II})$ & $\mathrm{Zn}(\mathrm{II})$ & $\mathrm{Co}(\mathrm{II})$ \\
\hline \multicolumn{5}{|c|}{ In (Water: Dioxane) (25:75) } \\
\hline (BHK-Me)-(Metal ion)- (BTAZ-Alk-OH) & -0.37 & -0.63 & -0.37 & -0.72 \\
\hline (BHK-Me)-(Metal ion)- (BTAZ-Ph-OH) & -0.39 & -0.51 & -0.19 & -0.53 \\
\hline (BHK-Me)-(Metal ion)- (BTAZ-Alk-NH $\left.{ }_{2}\right)$ & -0.42 & -0.62 & -0.38 & -0.79 \\
\hline (BHK-Me)-(Metal ion)- (BTAZ-Ph-NH $\left.{ }_{2}\right)$ & -0.28 & -0.58 & -0.31 & -0.84 \\
\hline \multicolumn{5}{|c|}{ In (Water: Dioxane) (50:50) } \\
\hline (BHK-Me)-(Metal ion)- (BTAZ-Alk-OH) & -0.35 & -0.61 & -0.38 & -0.71 \\
\hline (BHK-Me)-(Metal ion)- (BTAZ-Ph-OH) & -0.36 & -0.51 & -0.21 & -0.52 \\
\hline (BHK-Me)-(Metal ion)- (BTAZ-Alk-NH ${ }_{2}$ ) & -0.41 & -0.65 & -0.37 & -0.81 \\
\hline (BHK-Me)-(Metal ion)- (BTAZ-Ph-NH $\left.{ }_{2}\right)$ & -0.29 & -0.54 & -0.29 & -0.78 \\
\hline \multicolumn{5}{|c|}{ In (Water: Dioxane) (75:25) } \\
\hline (BHK-Me)-(Metal ion)- (BTAZ-Alk-OH) & -0.36 & -0.60 & -0.37 & -0.70 \\
\hline (BHK-Me)-(Metal ion)- (BTAZ-Ph-OH) & -0.39 & -0.61 & -0.37 & -0.66 \\
\hline (BHK-Me)-(Metal ion)- (BTAZ-Alk-NH ${ }_{2}$ ) & -0.36 & -0.62 & -0.35 & -0.72 \\
\hline (BHK-Me)-(Metal ion)- (BTAZ-Ph-NH ${ }_{2}$ ) & -0.35 & -0.64 & -0.34 & -0.7 \\
\hline
\end{tabular}

Table 10:- Quantification of stabilities of (BHK-Et)-metal (II)-BTAZ (1:1:1) ternary complexes in terms of $\Delta \log \mathrm{K}$ values at various mixed Solvent Systems

\begin{tabular}{|c|c|c|c|c|}
\hline \multirow[t]{2}{*}{ Ternary Complex } & \multicolumn{4}{|c|}{ Metal ion } \\
\hline & $\mathrm{Cu}(\mathrm{II})$ & $\mathrm{Ni}(\mathrm{II})$ & $\mathrm{Zn}(\mathrm{II})$ & $\mathrm{Co}(\mathrm{II})$ \\
\hline \multicolumn{5}{|c|}{ In (Water: Dioxane) (25:75) } \\
\hline (BHK-Et)-(Metal ion)- (BTAZ-Alk-OH) & -0.23 & -0.52 & -0.25 & -0.69 \\
\hline (BHK-Et)-(Metal ion)- (BTAZ-Ph-OH) & -0.25 & -0.42 & -0.11 & -0.56 \\
\hline (BHK-Et)-(Metal ion)- (BTAZ-Alk-NH $\left.{ }_{2}\right)$ & -0.35 & -0.53 & -0.27 & -0.67 \\
\hline (BHK-Et)-(Metal ion)- (BTAZ-Ph-NH ${ }_{2}$ ) & -0.21 & -0.43 & -0.19 & -0.67 \\
\hline \multicolumn{5}{|c|}{ In (Water: Dioxane) (50:50) } \\
\hline (BHK-Et)-(Metal ion)- (BTAZ-Alk-OH) & -0.22 & -0.51 & -0.23 & -0.7 \\
\hline (BHK-Et)-(Metal ion)- (BTAZ-Ph-OH) & -0.26 & -0.40 & -0.12 & -0.59 \\
\hline (BHK-Et)-(Metal ion)- (BTAZ-Alk-NH $\left.{ }_{2}\right)$ & -0.33 & -0.5 & -0.28 & -0.66 \\
\hline (BHK-Et)-(Metal ion)- (BTAZ-Ph-NH ${ }_{2}$ ) & -0.22 & -0.4 & -0.19 & -0.66 \\
\hline \multicolumn{5}{|c|}{ In (Water: Dioxane) (75:25) } \\
\hline (BHK-Et)-(Metal ion)- (BTAZ-Alk-OH) & 0.08 & 0.03 & 0.07 & 0.03 \\
\hline (BHK-Et)-(Metal ion)- (BTAZ-Ph-OH) & 0.07 & 0.04 & 0.06 & 0.03 \\
\hline (BHK-Et)-(Metal ion)- (BTAZ-Alk-NH $\left.{ }_{2}\right)$ & 0.12 & 0.06 & 0.11 & 0.04 \\
\hline (BHK-Et)-(Metal ion)- (BTAZ-Ph-NH $\left.{ }_{2}\right)$ & 0.13 & 0.06 & 0.11 & 0.06 \\
\hline
\end{tabular}

Table 11:- Quantification of stabilities of (BHK-Bu)-metal(II)-BTAZ (1:1:1) ternary complexes in terms of $\Delta \log \mathrm{K}$ values at various mixed Solvent Systems

\begin{tabular}{|c|c|c|c|c|}
\hline \multirow{2}{*}{ Ternary Complex } & \multicolumn{4}{|c|}{ Metal ion } \\
\cline { 2 - 5 } & $\mathrm{Cu}(\mathrm{II})$ & $\mathrm{Ni}(\mathrm{II})$ & $\mathrm{Zn}$ (II) & $\mathrm{Co}$ (II) \\
\hline \multicolumn{2}{|c|}{ In (Water: Dioxane) (25:75) } \\
\hline (BHK-Bu)-(Metal ion)- (BTAZ-Alk-OH) & 0.08 & 0.01 & 0.05 & 0.01 \\
\hline (BHK-Bu)-(Metal ion)- (BTAZ-Ph-OH) & 0.07 & 0.02 & 0.06 & 0.01 \\
\hline (BHK-Bu)-(Metal ion)- (BTAZ-Alk-NH 2$)$ & 0.14 & 0.05 & 0.09 & 0.06 \\
\hline
\end{tabular}




\begin{tabular}{|c|c|c|c|c|}
\hline (BHK-Bu)-(Metal ion)- (BTAZ-Ph-NH $\left.{ }_{2}\right)$ & 0.13 & 0.06 & 0.09 & 0.05 \\
\hline \multicolumn{5}{|c|}{ In (Water: Dioxane) (50:50) } \\
\hline (BHK-Bu)-(Metal ion)- (BTAZ-Alk-OH) & 0.17 & 0.02 & 0.11 & 0.03 \\
\hline (BHK-Bu)-(Metal ion)- (BTAZ-Ph-OH) & 0.15 & 0.04 & 0.14 & 0.03 \\
\hline (BHK-Bu)-(Metal ion)- (BTAZ-Alk-NH $\left.{ }_{2}\right)$ & 0.34 & 0.11 & 0.22 & 0.12 \\
\hline (BHK-Bu)-(Metal ion)- (BTAZ-Ph-NH $\left.{ }_{2}\right)$ & 033 & 0.12 & 0.21 & 0.11 \\
\hline \multicolumn{5}{|c|}{ In (Water: Dioxane) (75:25) } \\
\hline (BHK-Bu)-(Metal ion)- (BTAZ-Alk-OH) & 0.37 & 0.06 & 0.24 & 0.07 \\
\hline (BHK-Bu)-(Metal ion)- (BTAZ-Ph-OH) & 0.34 & 0.05 & 0.21 & 0.07 \\
\hline (BHK-Bu)-(Metal ion)- (BTAZ-Alk-NH $\left.{ }_{2}\right)$ & 0.46 & 0.18 & 0.30 & 0.19 \\
\hline (BHK-Bu)-(Metal ion)- (BTAZ-Ph-NH ${ }_{2}$ ) & 0.46 & 0.19 & 0.31 & 0.19 \\
\hline
\end{tabular}

Table 12:- Quantification of stabilities of (BHK-Ph)-metal (II)-BTAZ (1:1:1) ternary complexes in terms of $\Delta \log$ $\mathrm{K}$ values at various mixed Solvent Systems

\begin{tabular}{|c|c|c|c|c|}
\hline \multirow[t]{2}{*}{ Ternary Complex } & \multicolumn{4}{|c|}{ Metal ion } \\
\hline & $\mathrm{Cu}(\mathrm{II})$ & $\mathrm{Ni}(\mathrm{II})$ & $\mathrm{Zn}(\mathrm{II})$ & $\mathrm{Co}(\mathrm{II})$ \\
\hline \multicolumn{5}{|c|}{ In (Water: Dioxane) (25:75) } \\
\hline (BHK-Ph)-(Metal ion)- (BTAZ-Alk-OH) & 0.22 & 0.08 & 0.16 & 0.06 \\
\hline (BHK-Ph)-(Metal ion)- (BTAZ-Ph-OH) & 0.21 & 0.08 & 0.16 & 0.08 \\
\hline (BHK-Ph)-(Metal ion)- (BTAZ-Alk-NH $\left.{ }_{2}\right)$ & 0.22 & 0.11 & 0.20 & 0.12 \\
\hline (BHK-Ph)-(Metal ion)- (BTAZ-Ph-NH $\left.{ }_{2}\right)$ & 0.25 & 0.12 & 0.23 & 0.12 \\
\hline \multicolumn{5}{|c|}{ In (Water: Dioxane) (50:50) } \\
\hline (BHK-Ph)-(Metal ion)- (BTAZ-Alk-OH) & 0.67 & 0.13 & 0.39 & 0.13 \\
\hline (BHK-Ph)-(Metal ion)- (BTAZ-Ph-OH) & 0.68 & 0.16 & 0.41 & 0.16 \\
\hline (BHK-Ph)-(Metal ion)- (BTAZ-Alk-NH $\left.{ }_{2}\right)$ & 0.81 & 0.26 & 0.55 & 0.19 \\
\hline (BHK-Ph)-(Metal ion)- (BTAZ-Ph-NH ${ }_{2}$ ) & 0.82 & 0.25 & 0.52 & 0.17 \\
\hline \multicolumn{5}{|c|}{ In (Water: Dioxane) (75:25) } \\
\hline (BHK-Ph)-(Metal ion)- (BTAZ-Alk-OH) & 0.95 & 0.19 & 0.51 & 0.19 \\
\hline (BHK-Ph)-(Metal ion)- (BTAZ-Ph-OH) & 0.94 & 0.19 & 0.49 & 0.18 \\
\hline (BHK-Ph)-(Metal ion)- $\left(\right.$ BTAZ-Alk-NH $\left.{ }_{2}\right)$ & 1.14 & 0.36 & 0.59 & 0.23 \\
\hline (BHK-Ph)-(Metal ion)- (BTAZ-Ph-NH $\left.{ }_{2}\right)$ & 1.15 & 0.35 & 0.57 & 0.23 \\
\hline
\end{tabular}

It appears that there is no change in the $\Delta \log \mathrm{K}$ values for the interaction of metal ions with BHK-Me and BTAZ derivatives in various amounts of solvents studied. This is expected because the methyl side chain on BHK ligand cannot reach the BTAZ ligand, and therefore no ligand-ligand interactions present in this system.

Interestingly, the interaction of metal ions with BHK-Et and BTAZ derivatives showed unexpected results. The $\Delta$ $\log \mathrm{K}$ values are slightly positive for the BKH-Et ternary systems at 75:25 Water : Dioxane solvent system. However, $\Delta \log \mathrm{K}$ values are negative and there is no change in the $\Delta \log \mathrm{K}$ values for BKH-Et ternary systems at 25:75 and 50:50 Water : Dioxane solvent system. This suggests that increase in the water content in the solvent system favors the ligand-ligand interactions. In this case, the ethyl side chain attached to the BHK slightly overlaps with the aromatic moiety of BTAZ derivative.

In the above solvent mediated ligand-ligand interactions there are two possibilities for the ethyl group to interact with BTAZ derivative. The first one is heterocyclic ring and the second one is phenyl moiety. Our data shows the $\Delta$ $\log \mathrm{K}$ values are about the same for BTAZ with aromatic side chain and BTAZ with aliphatic side chain. Therefore, it is likely to overlap with the heterocyclic ring of BTAZ derivative rather than phenyl moiety. Based on these evidences, we propose the following model for the ternary complex of (BHK-Et)-M-(BTAZ-X), where X is -OH or $\mathrm{NH}_{2}$, in 75:25 Water : Dioxane solvent system: 


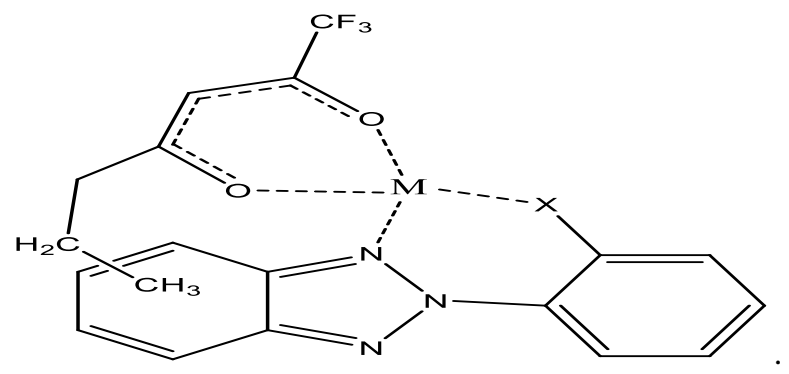

The above solvent mediated ligand-ligand interaction in the BHK-Et with one of the BTAZ derivatives in the presence of metal ions can be represented by the following scheme:

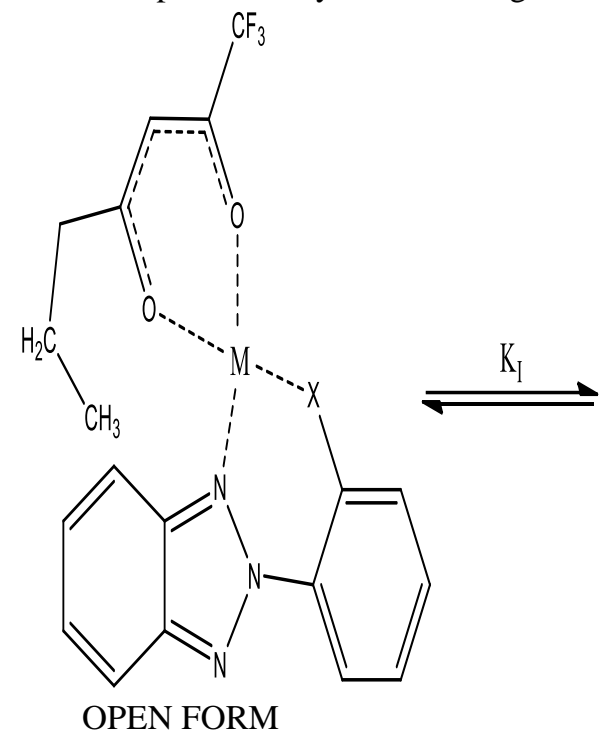

OPEN FORM

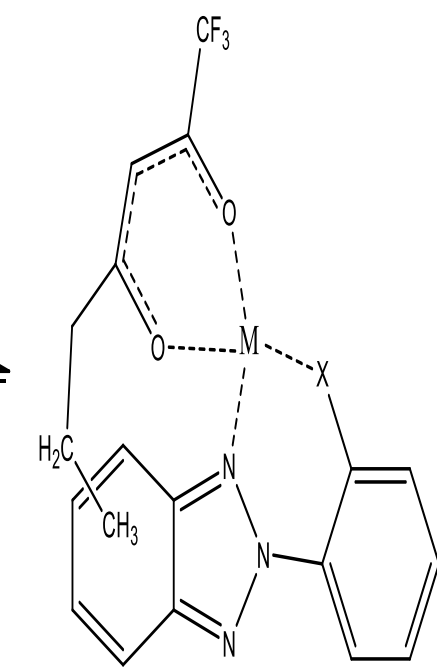

CLOSED FORM

In 50:50 Water : Dioxane solvent system

In 75:25 Water : Dioxane solvent system

The above equilibrium can be quantified in terms of $\mathrm{K}_{\mathrm{I}}$ and percentage of stacking.

$\mathrm{KI}=(10 \Delta \log \mathrm{K})-1(1)$

$\%$ of $($ Ternary Complex $)$ stacking $=(\mathrm{KI} /(1+\mathrm{KI})) * 100$

The $\mathrm{K}_{\mathrm{I}}$ is intra-molecular equilibrium constant, which is a dimensionless constant [102-105]. The quantified data for the above equilibrium is listed in the Table 13.

Table 13:- Quantification of ligand-ligand interactions in (BHK-Et)-metal (II)-BTAZ (1:1:1) ternary complexes in terms of Intra-molecular equilibrium constant $\left(\mathrm{K}_{\mathrm{I}}\right)$ and

Percentage of Stacking ${ }^{\ddagger}$

\begin{tabular}{|c|c|c|c|c|c|c|}
\hline \multirow[b]{2}{*}{ Ternary Complex } & & \multirow{2}{*}{$\begin{array}{l}\mathrm{K}_{\mathrm{I}} \text { and } \\
\% \text { of Stacking }\end{array}$} & \multicolumn{4}{|c|}{ Metal ion } \\
\hline & & & $\mathrm{Cu}(\mathrm{II})$ & $\mathrm{Ni}(\mathrm{II})$ & $\mathrm{Zn}(\mathrm{II})$ & $\mathrm{Co}(\mathrm{II})$ \\
\hline \multirow{2}{*}{$\begin{array}{l}\text { (BHK-Et)-(Metal } \\
\text { (BTAZ-Alk-OH) }\end{array}$} & \multirow[t]{2}{*}{ ion)- } & $\mathrm{K}_{\mathrm{I}}$ & 0.20 & 0.07 & 0.17 & 0.07 \\
\hline & & $\%$ of Stacking & 16.82 & 6.67 & 14.89 & 6.67 \\
\hline \multirow{2}{*}{$\begin{array}{l}\text { (BHK-Et)-(Metal } \\
\text { (BTAZ-Ph-OH) }\end{array}$} & \multirow[t]{2}{*}{ ion)- } & $\mathrm{K}_{\mathrm{I}}$ & 0.17 & 0.10 & 0.15 & 0.07 \\
\hline & & $\%$ of Stacking & 14.89 & 8.80 & 12.90 & 6.67 \\
\hline \multirow{2}{*}{$\begin{array}{l}\text { (BHK-Et)-(Metal } \\
(\text { BTAZ-Alk-NH2) }\end{array}$} & \multirow[t]{2}{*}{ ion)- } & $\mathrm{K}_{\mathrm{I}}$ & 0.32 & 0.15 & 0.26 & 0.10 \\
\hline & & $\%$ of Stacking & 24.14 & 12.90 & 20.57 & 8.80 \\
\hline \multirow{2}{*}{$\begin{array}{l}\text { (BHK-Et)-(Metal } \\
\text { (BTAZ-Ph-NH }{ }_{2} \text { ) }\end{array}$} & \multirow{2}{*}{ ion)- } & $\mathrm{K}_{\mathrm{I}}$ & 0.35 & 0.15 & 0.29 & 0.15 \\
\hline & & $\%$ of Stacking & 25.87 & 12.90 & 22.38 & 12.90 \\
\hline
\end{tabular}

$¥$ overlap between the ethyl side chain of BHK over the heterocyclic ring of benzotriazole.

$\mathrm{KI} \pm 0.05, \%$ of stacking \pm 2

According to the data from Table 13, the intra-molecular equilibrium constant is high for copper complexes compared to other metal ternary complexes. The percentage of stacking is also high for copper complexes, followed 
by zinc complexes and about the same for nickel and cobalt complexes. This suggests that these complexes exist in different forms in different solvent systems and the ligand-ligand interactions are highly sensitive to the medium.

For the other ternary systems, viz., for the interaction of BHK-Bu with BTAZ derivatives in the presence of metal ions, the $\Delta \log \mathrm{K}$ values showed positive in all solvent systems, increases with increase in the water content in the solvent system.

Similarly, the $\Delta \log \mathrm{K}$ values, for the interaction of BHK-Ph with BTAZ derivatives in the presence of metal ions, also increases with increase in the water content in the solvent system.

The above systems also showed in increase in the percentage of ligand-ligand interactions with increase in the water content in the solvent system.

Of all the ternary systems studies at various solvent systems, the BTAZ with N-N donors showed higher stabilities compared to the BTAZ with N-O donor atoms in 75:25 (Water : Dioxane) solvent system. This is because of the absence of electrostatic repulsion between the donor atoms of the two ligands, ternary complexes involving N-N donor ligands from BTAZ ligands are destabilized to lesser extent than the corresponding complexes containing dinegative oxygen donor ligands from BHK ligands.

According to the data from the tables, the stability constants decrease in the order $\mathrm{Zn}<\mathrm{Cu}>\mathrm{Ni}>\mathrm{Co}$, which is the natural order of stability.

\section{Conclusions:-}

We report stabilities of ternary complexes of metal ions (copper, nickel, zinc and cobalt) with beta-hydroxy ketone derivatives and benzotriazole derivatives in various mixed solvent systems (Water+Dioxane) using $\mathrm{pH}$ metric method. The calculated data suggests that the copper forms more stable complexes, which is followed by zinc and $\mathrm{Ni}$ complexes with these ligands. Cobalt form less stable complexes with these ligands. The stabilities of these complexes are quantified with $\Delta \log \mathrm{K}$ values, intra-molecular equilibrium constants and percentage of stacking interaction in the ternary systems. The striking positive $\Delta \log \mathrm{K}$ values suggest that side chain ethyl, butyl and phenyl moiety in BHK ligand overlaps with the aromatic moiety of BTAZ ligand in the ternary complex, which results in the enhanced stabilities for the (BHK-Alk)/(BHK-Ph)-Metal(II)-BTAZ system.

Interestingly, the $\Delta \log \mathrm{K}$ values for both (BHK-Alk)/(BHK-Ph)-Metal(II)-(BTAZ-Alk-OH) and (BHK-Alk)/(BHK$\mathrm{Ph})$-Metal(II)-(BTAZ-Ph-OH) are about the same. This suggests the aromatic moiety of BHK is overlapping with the triazole ring, but not the phenoxy ring of the BTAZ ligand.

In view of the utilities of metal complexes of beta-hydroxy ketone and benzotriazole derivatives in the chemical and biochemical fields, the established unexpected stabilities, from the intramolecular interactions, for the reported ternary complexes may serve as good model complexes in the design and development of metal-ligand complexes. The ligand-ligand interactions in the metal-ligand complexes are directly related to the overall stability of the metalligand complexes.

\section{References:-}

1. J.Porath, Protein Expression and Purification, vol.3, issue 4, August 1992, pages 263-281.

2. F.S.Richardson, Chem.Rev., 1982, 82, 541-552.

3. B.H.Ye, M.L.Tong, X.M.Chen, Coordination Chemistry Reviews, 2005, vol.249, issues 5-6, pages 545-565.

4. M.F.Dunn, BioMetals, 2005, 18:295-303.

5. B.P.Hay, R.D.Hancock, Coordination Chemistry Reviews, 2001, vol.212, issue1, pages 61-78.

6. V.I.Slaveykova, K.J.Wilkinson, Environmental Chemistry, 2005, vol.2, issue 1, pages 9-24.

7. M.D.Allendorf, C.A.Bauer, R.K.Bhakta, R.J.T.Houk, Chem.Soc.Rev., 2009, 38, 1330-1352.

8. M.J.Haydon, C.S.Cobbett, 2007, vol.174, Issue 3, pages 499-506.

9. L.Rulisek, and Z.Havles, J.Am.Chem.Soc., 2000, 122(42), pp 10428-10439.

10. T.Katsuki, Chem.Soc.Rev., 2004, 33, 437-444.

11. T.Storr, K.H.Thompson, and C.Orvig, Chem.Soc.Rev., 2006, 35, 534-544.

12. P.K.Sasmal, C.N.Streu, and E.Meggers, Chem.Commun., 2013, 49, 1581. 
13. R.Crichton, in Biological Inorganic Chemistry: A new introduction to molecular structure and fuction, 2012, $2^{\text {nd }}$ edition, Elsevier UK.

14. K.L.Haas, and K.J.Franz, Chem.Rev., 2009, 109, 4921-4960.

15. D.X.West, S.B.Pandhye, and P.B.Sonawane, Complex Chemistry: Structure and Bonding, 1991, vol.76, pp 150.

16. 16. M.Grazul, E.Budzisz, Coordination Chemistry Reviews, 2009, vol.253, issues 21-22, pages 2588-2598.

17. V.Barve, F.Ahmed, S.Adsule, S.Banerjee, S.Kulkarni, P.Katiyar, C.E.Anson, A.K.Powell, S.Padhya, and F.H.Sarkar, J.Med.Chem., 2006, 49(13), pp 3800-3808.

18. Z.H.Chohan, M.Arif, M.A.Akhtar, and C.T.Supuran, Bioinorganic Chemistry and Applications, 2006, vol.2006, pages 1-13.

19. K.Singh, M.S.Barwa, and P.Tyagi, Eur.J.of Med.Chem., 2006, vol.41, issue 1, pages 147-153.

20. C.J.Fahrni, Current Opinion in Chemical Biology, 2007, vol.11, issue 2, pages 121-127.

21. E.Meggers, Current Opinion in Chemical Biology, 2007, vol.11, issue 3, pages 287-292.

22. Selvaraj et al, Medicinal Research Reviews, 2013, vol.34, issue 4, pages 677- 892.

23. C.X.Zhang and S.J.Lippard, Current Opinion in Chemical Biology, 2003, 7:481-489.

24. N.Farrell, in Comprehensive Coordination Chemistry II, 2003, 809-840, Elsevier Ltd.

25. L.Giovagnini, S.Sitran, M.Montopoli, L.Caparrotta, M.Corsini, C.Rosani, P.Zanello, Q.P.Dou, and D.Fregona, Inorganic Chemistry, 2008, 47(14), pp 6336-6343.

26. C.G.Hartinger, A.A.Alexey, S.M.Ashraf, P.J.Dyson, and B.K.Keppler, Current Medicinal Chemistry, 2008, vol.15, No. 25, pages 2574-2591 (18).

27. P.C.A.Bruijnincx, and P.J.Sadler, Current Opinion in Chemical Biology, 2008, vol.12, issue 2, pages 197-206.

28. S.Adsule, V.Barve, D.Chen, F.Ahmed, Q.P.Dou, S.Pandhye, and F.H.Sarkar, J.Med.Chem., 2006, 49(24), pp $7242-7246$.

29. A.Gaeta, and R.C.Hider, British Journal of Pharmacology, 2005, vol.146, issue 8, pages 1041-1059.

30. C.Orvig, and M.J.Abrams, Chemical Reviews, 1999, vol.99, number 9, pages 2201-2203 .

31. V.Sharma, and D.Piwnica-Worms, Chem.Rev., 1999, 99, 2545-2560.

32. R.Schibli, R.Schwarzbach, R.Alberto, K.Ortner, H.Schmalle, C.Dumas, A.Egli, and P.A.Schubiger, Bioconjugate Chem., 2002, 13(4), pp. 750-756.

33. K.H. Thompson, B. D. Liboiron, Y. Sun, K. D. Bellman, I. A. Setyawati, B.O.Patrick, V. Karunaratne, G. Rawji, J. Wheeler, K. Sutton, S. Bhanot, C.Cassidy, J. H. McNeill, V. G. Yuen, and C. Orvig, J.Biol.Inorg.Chem., 2003, vol.8, issue 1-2, pp 66-74.

34. Z.D, Liu, and R.C. Hider, Coordination Chemistry Review, 2002, vol.232, issues 1-2, pages 151-171.

35. J.D.Slinker et al, Journal of Material Chemistry, 2007, 17, 2976-2988.

36. H.Xu et al, Chem.Soc.Rev., 2014, 43, 3259.

37. S-J.Liu, Y.Chen, W-J.Xu, Q.Zhao, and W.Huang, Macromol.Rapid Commun., 2012, 33, 461-480.

38. P. Chaudhuri, C.N.Verani, E.Bill, E.Bothe, T.Weyhermuller, and K.Wieghardt, J.Am.Chem.Soc., 2001, 123(10), pp 2213-2223.

39. S.Lamansky, P.Djurovich, D.Murphy, F.A.Razzaq, H.E.Lee, C.Adachi, P.E. Burrows, S.R. Forrest, and M.E.Thompson, J.Am.Chem.Soc., 2001, 123(18), pp. 4304-4312 .

40. V.Balzani, S.Campagna, G.Denti, A.Juris, S.Serroni, and M.Venturi, Acc.Chem.Rev., 1998, 31, 26-34.

41. V.W.Yam, and K.K.Lo, Chem.Soc.Rev., 1999, 28, 323-334.

42. V.W.Yam, Acc.Chem.Res., 2002, 35(7), pp 555-563.

43. T.H.Kwon, H.S.Cho, M.K.Kim, J.W.Kim, J.J.Kim, K.H.Lee, S.J.Park, I.S.Shin, H.Kim, D.M.Shin, Y.K.Chung, and J.I.Hong, Organometallics, 2005, 24(7), pp. 1578-1585.

44. J.Slinker, D.Bernards, P.L.Houston, H.D.Abruna, S.Bernhard, and G.G.Malliaras, Chem.Commun. 2003, 23922399.

45. J.N. Demas, and B.A. DeGraff, Anal.Chem. 1991, 63(17), pp 829A-837A.

46. F.Hua, S.Kinayyigit, J.R.Cable, and F.N.Castellano, Inorg.Chem., 2005, 44(3), pp. 471-473.

47. C.H.Chen, and J.Shi, Coordination Chemistry Reviews, 1998, vol.171, pages161-174.

48. T.A.White, S.M.Arachchige, B.Sedai, and K.J.Brewer, Materials, 2010, 3(8), 4328-4354.

49. M.M.Henary, and C.J.Fahrni, J.Phys.Chem.A., 2002, 106, 5210-5220.

50. E.Terpetschnig, H.Szmacinski, H.Malak, and J.R.Lakowicz, Biophys. J., 1995, 68(1), 342-350.

51. Y.Xiang, A.Tong, P.Jin, and Y.Ju, Org.Lett., 2006, 8(13), pp.2863-2866.

52. R. Krämer, Angew. Chem., Int. Ed. 1998, 37, 772.

53. Valeur, B.; Leray, I. Coord. Chem. Rev. 2000, 205, 3. 
54. K.Aslan, I.Gryczynski, J.Malicka, E.Matveeva, J.R.Lakowicz, C.D.Geddes, Current Opinion in Biotechnology, 2005, vol.16, issue 1, pages 55-62.

55. D.Wu, W.Huang, C.Duan, Z.Lin, and Q.Meng, Inorg.Chem., 2007, 46(5), 1538-1540.

56. M.Hee, and S.J.Lippard, Acc.Chem.Res., 2007, 40(1), pp. 41-51.

57. Lim, M. H.; Xu, D.; Lippard, S. J., Nat. Chem. Biol. 2006, 2, 375-380.

58. C.P.Montgomery, B.S.Murray, E.J.New, R.Pal, and D.Parker, Acc.Chem.Res.,2009, 42(7), pp. 925-937.

59. A.Malik, S.Parveen, T.Ahamad, S.M.Alshehri, P.K.Singh, and N.Nishat, Bioinorganic Chemistry and Applications, 2010, vol.2010, pages 1-8.

60. S.D.Alexandratos, Ind.Eng.Chem.Res., 2009, 48, 388-398.

61. R.D.Mazurat, and S.Pesun, J.Can.Dent.Assoc., 1998, 64(7), 503-7.

62. E.Hochuli, H.Dobeli, and A.Schacher, Journal of Chromatography A, 1987, vol.411, pages 177-184.

63. Y.Kato, K.Nakamura, and T.Hashimoto, Journal of Chromatrography A, 1986, vol.354, pages 511-517.

64. E. Hochuli ${ }^{1,}$ ", W. Bannwarth ${ }^{1}$, H. Döbeli ${ }^{1}$, R. Gentz ${ }^{1} \&$ D. Stüber, Nature Biotechnology, 1988, 6, 1321-1325.

65. S.Akgol, and A.Denizli, Journal of Molecular Catalysis B: Enzymatic, 2004, vol.28, issue 1, pages 7-14.

66. P.K.Bhattacharya, Metal ions in biochemistry, 2005, Alpha Science international Ltd.

67. J.B.Waern, and M.M.Harding, Inorg.Chem., 2004, 43(1), pp.206-213.

68. L.E.H.Paul, B.Therrien, and J.Furrer, Inorg.Chem., 2012, 51(2), pages 1057-1067.

69. L.Pellerito, and L.Nagy, Coordination Chemistry Reviews, 2002, vol.224, issues 1-2, pages 111-150.

70. T.Dudev, and C.Lim, J.Am.Chem.Soc., 2000, 122(45), pages 11146-11153.

71. A.I.Bush, Neurobiology of Aging, 2002, vol.23, issue 6, pages 1031-1038.

72. K.A.Price, P.J.Crouch, and A.R.White, Recent Patents on CNS Drug Discovery, 2007, vol.2, No.3, pp. 180187(8).

73. T.Egli, Journal of Bioscience and Bioengineering, 2001, vol.92, issue 2, pages 89-97.

74. A.Maia, D.Landini, B.Leska, and G.Schroeder, Tetrahedron Letters, 2003, vol.44, issue 21, pages 4149-4151.

75. A. Guttman, A.Paulus, A.S.Cohen, N.Grinberg, and B.L.Karger, Journal of Chromatrography A, 1988, vol.448, pages 41-53.

76. A.S.Borovik, Acc.Chem.Res., 2005, 38(1), pp 54-61.

77. D.Zhao, D.J.Timmons, D.Yuan, and H.C.Zhou, Acc.Chem.Res., 2011, 44(2), pp.123-133.

78. B.Kesanli, and W.Lin, Coordination Chemistry Reviews, 2003, vol.246, issues 1-2, pages 305-326.

79. R.D.Hancock, M.S.Shaikjee, S.M.Dobson, and J.C.A.Boeyens, Inorganic Chimica Acta, 1988, vol.154, issue 2, pages 229-238.

80. A.L.Gavrilova, and B.Bosnich, Chem.Rev., 2004, 104, 349-383.

81. W.J.O'Sullivan, and G.W. Smithers, Methods in Enzymology, 1979, vol.63, pages 294-336.

82. G,Liang, R.Tribolet, and H.Sigel, Inorg.Chem., 1988, 27, 2877-2887.

83. NIST Critically selected stability constants of metal complexes, http://www.nist.gov/srd/nist46.cfm

84. A.E.Martel and R.M.Smith, Critical stability constants, 1974-1989, vol.1-6, Plenum Press, NY.

85. P.W.Dimmock, P,Warwick, and R.A.Robbins, Analyst, 1995, vol.120, pages 2159-2170.

86. B.E.Fischer, and H.Sigel, J.Am.Chem.Soc., 1980, 102(9), 2998-3008.

87. H.Sigel, Pure \& Appl.Chem., 1989, vol.61, No.5, 9.23-932.

88. R.R. Khoury, G.J. Sutton, D. Ebrahimi, and D.B. Hibbert, Inorganic Chemistry, 2014, 53(3), pages 1278-1287.

89. B. Knobloch, A. Mucha, B.P. Operschall, H. Sigel, M.J. Bojczuk, H. Kozlowski, and R.K.O. Sigel, Chem.Eur.J., 2011, 17, 5393-5403.

90. V.B. Kenche, I. Zawisza, C.L. Masters, W.Bal, K.J. Barnham, and S.C. Drew, Inorganic Chemistry, 2013, 52(8), pages 4303-4318.

91. J.M. Hernando, O. Montero, and C. Blanco, Journal of Solution Chemistry, 1990, vol.19, No.12, 1191-1197.

92. M.J. Go, J.M. Lee, K.M. Lee, C.H. Oh, K.H. Park, S.H. Kim, M. Kim, H.R. Park, M.H. Park, Y. Kim, J. Lee, Polyhedron, 2014, vol.67, 286-294.

93. G.Schwarzenbach, Complexometric titrations (Interscience, New York), 1957, p.77.

94. G. Schwarzenbach, and R. Biedermann, Helv.Chim.Acta, 1948, 31, 311.

95. A.E. Martel and R.J. Motekaitis, "Determination and Use of Stability Constants", VCH Publishers, New York, 1992.

96. F.Gharib, M.Jabbari, A.Farajtabar, and A.Shamel, J.Chem.Eng.Data, 2008, 53(8), 1772-1778.

97. O.M.El-Roudi, and S.A.Abdel-Latif, J.Chem.Eng.Data, 2004, 49(5), 1193-1196.

98. H.Sigel, R,M.Balakrishnan, and U.K.Haring, J.Am.Chem.Soc., 1985,107,5137-5148.

99. Sándor Kunsági-Máté, Ashok Kumar, Pratibha Sharma, László Kollár and Martin Pour Nikfardjam, The Journal of Physical Chemistry-B, 2009, 113 (21), 7468-7473. 
100.Begoña García, Saturnino Ibeas, Rebeca Ruiz, José M. Leal, Tarita Biver, Alessia Boggioni, Fernando Secco and Marcella Venturini, he Journal of Physical Chemistry B, 2009, 113 (1), 188-196.

101.Hans Joerg. Schneider, Ruediger. Kramer, Svetlana. Simova, Ulrich. Schneider, Journal of the American Chemical Society, 1988, 110(19), 6442-6448.

102.S.A.Sajadi, B.Song, F.Gregan, and H.Sigel, Bull.Chem.Soc.Ethiop., 1997, 11(2), 121-130.

103.S.S.Massoud, H.Sigel, Inorg.Chim.Acta, 1989, 159, 243-252.

104.H.Sigel, R.Tribolet, K.H.Scheller, Inorg.Chim.Acta, 1985, 100, 151-164.

105.S.S.Massoud, R.Tribolet, H.Sigel, Eur.J.Biochem., 1990, 187, 387-393. 